\title{
The Process of Exchange, Solidarity and Sustainable Development in Building a Community of Responsibility
}

\author{
Ph.D. Damian Walczak \\ Faculty of Economic Sciences and Management, Nicolaus Copernicus University in Torun, Poland \\ Email:dwalczak@umk.pl
}

\section{Doi:10.5901/mjss.2015.v6n1s1p506}

\section{Abstract}

Nowadays an exchange process proceeds much faster and more frequently than ever before. Primitive societies were engaged in the exchange of individual products, services, ceremonies or women. Currently, we exchange on a global scale many products, services, privileges, etc. However, one aspect has remained practically unchanged - nobody within the exchange process wants to be marginalized and aggrieved. The fairness of a global exchange process understood in that way constitutes a reference to solidarity, which is based on mutual interests. Every society can probably function far away from the principles of solidarity, submitting an individual above the community or the community above an individual. However, an individual's dissatisfaction, or dissatisfaction of more numerous individuals involved in the exchange process must exert a negative impact on the development of the entire community. However, solidarity based on common interests is insufficient. Society should strive to create a full community of responsibility. Such a community can be created only by a group of people who on their own - individually - approach positively their exchange process and also create a responsible community. This community should think not only about each individual, but also about its proper (sustainable) development, namely about the future of all its members (including also those yet unborn). For this reason, the aim of the study was to present the process of exchange and solidarity in terms of building a community of responsibility.

Keywords: exchange theory; solidarity; social equity theory; reciprocity; community of responsibility;

\section{Introduction}

According to Dewey exchange has always been part of human life, which is dependent on the 'give-and-take' relationship (Dewey, 1984). The principle of exchange, which had resulted in mutual courtesy recitation, rituals, services, markets, and even (or especially) women was already applied by primitive societies. Mauss (1966) indicates that the system defined by him as a system of total prestations was a feature of community since community took mutual obligations, was involved in exchange (he defines the subject of exchange as 'Gift') and decision-making processes, though, of course, the physical exchange was realised by appropriate units ${ }^{1}$. Mauss (1966) also emphasizes that in many primitive societies exchanging resulted from the will of attaching other people - 'to put people under obligations', because "in theory such gifts are voluntary, but in fact they are given and repaid under obligation". Berne (1967) said that 'any social intercourse (...) has a biological advantage over no intercourse at all', so, according to him, we need, like a child, any form of 'stroking' (a physical contact, e.g., exchange) to live.

Malinowski defines one of the forms of exchange in primitive societies with the concept of Kula. It is an intertribal exchange of only two items that creates long-term social relationships between the participants, according to the saying 'once in the Kula, always in the Kula' (more: Malinowski, 1922). In turn, Levi-Strauss points out that in any society communication takes place on three levels: circulation of women, of goods (services) and remittances. Each form of communication is that in order to increase own benefits ${ }^{2}$ at the expense of others (an individual, a group), of course, offering others (an individual, a group) replaceable messages (Levi-Straus, 1963).

Similar indications were made in the Quran - references were made to the necessity for providing charity (help 'sadaqa') to others in one's own interest (The Quran, sura LXIV, verse 16). Also, Catholic social teaching emphasizes the role of the balance between property and behaviours of individuals and their obligations to the community to which they belong. Therefore it assumes the need for cooperation, which, as a matter of fact, is initiated by one's own interest

${ }^{1} \mathrm{~A}$ unit is understood throughout the whole work as a person or a group of people who act as a single entity within an exchange process (a professional group applying for pension benefits).

2 We can also use the word "reward". 
(Adamiak \& Walczak, 2014).

Nowadays, there is much written and said about the necessity of an appropriate, from the point of view of a unit and of the community, exchange process (solidarity); however, it must be noted that this statement is abused in particular by politicians. We should be in solidarity with other regions, countries, persons with disabilities, the retired or with certain professional groups (Paskov \& Dewilde, 2012; Kawiński, Stanko \& Rutecka, 2012; Chybalski, 2012). What is the reason of such behaviour? Is it a contemporary fashion or an element rooted deeply in human nature? Perhaps the concept of solidarity is being abused, or maybe one of the parties to the exchange process, following the principle of solidarity, receives more than they offer themselves.

\section{Methodology}

According to literature solidarity is inseparably linked to the community in which it is to be implemented (Yamagishi \& Mifune, 2009). However, both the community and the unit should be obliged to take care of providing a decent life for future generations - in accordance with the principle of sustainable development. Also correct perception of solidarity from the point of view of a unit and of the community as well as the concern for the development prospects of future generations are essential if the community is to have a positive impact on a decent life for future generations. Firstly, it must be emphasized that actions resulting from solidarity and sustainable development are based on the rights deriving from social exchange theory (Blau, 1964). Secondly, replacing resulting from solidarity and sustainable development probably is based also on an institutional exchange and not on the individual exchange (in which decisions are taken by the individual units). In the institutional exchange the tangible exchange is made by units, but the decisions are taken by the community - like most of the decisions resulting from the solidarity and sustainable development (Blau, 1964; Emerson, 1976). Additionally sustainable development in its many aspects (economic and social) refers to the issues that have also been considered by solidarity - solidarity in economic relations or solidarity in social relations. Also in the environmental context (third dimensions of sustainable development) solidaristic behaviours exert a positive impact on the environment, and the formulation of environmental solidarity is commonly used by the EU institutions (Ross \& Borgman-Prebil, 2010). Such coexistence of the solidarity and sustainable development can be referred to as 'sustainable society', 'sustainable solidarity' or, the already mentioned, 'environmental solidarity' (Nikolaidis \& Viehoff, 2012; Speth, 1992). The author in the paper proposes the term 'community of responsibility', which combines the behaviours deriving from the principle of solidarity and of sustainable development, which are to serve the economic development of the entire community that is favourable in terms of an individual and the community.

The purpose of this paper is to present the process of exchange ${ }^{3}$, solidarity and sustainable development in building a community of responsibility. Due to the mentioned above research area of the paper, it is based mainly on a literature research methodology (Lin, 2009).

\section{Exchange Process}

Approaching human relationships as a process created by the analysis of costs incurred and benefits obtained was reflected in the Social Exchange Theory according to which people determine the reciprocal relationship based on a common (reciprocal) interest. They offer possessed tangible and intangible benefits to others and expect in return possible individual benefits (Shtatfeld \& Barak, 2009; Lawler, 2011). These are reciprocity and repayment that are the most common and perhaps the best well-known forms (principles) of exchange (Cropanzano \& Mitchell, 2005). Meeker (1971) points out that within the exchange process, each unit takes into account at least the following elements: reciprocity, rationality, altruism (social responsibility), group gain, status, consistency, and competition (rivalry). A fuller list, which contains the items indicated above and also relates to the holistic approach to the problem, could include altruism (defined as actions undertaken for the benefit of the community), reciprocity, egoism (i.e., self-interest) and vindictiveness.

Exchange in the case of each individual depends on his/her personality traits. Under the same circumstances an altruist who has not received any 'gift' is able to offer something from himself/herself but a vengeful person in reaction to the lack of that gift not only gives nothing in return but also seeks to punish the other person with a negative provision. Table 1 shows the impact of personality factors on the process of exchange.

${ }^{3}$ According to Berne (1967) 'it is more useful and enlightening to investigate (...) transactions from the point of view of the advantages gained than to treat them as defensive operations', so this paper highlights the relation benefits/cost in the exchange process and not a defensive decision in this process. 
Table 1. Benefits connected with altruism, egoism, reciprocity, vindictiveness

\begin{tabular}{|c|c|c|}
\hline individual & benefits direction (0 means without benefits) & individual/community \\
\hline \multicolumn{3}{|c|}{ altruism (community) } \\
\hline A & 0 & B \\
\hline A & $\longrightarrow$ & B \\
\hline \multicolumn{3}{|c|}{ reciprocity } \\
\hline A & $\leftarrow$ & $\mathrm{B}$ \\
\hline A & $\longrightarrow$ & B \\
\hline \multicolumn{3}{|c|}{ egoism (self-interest) } \\
\hline A & $\leftarrow$ & B \\
\hline A & 0 & $\mathrm{~B}$ \\
\hline \multicolumn{3}{|c|}{ vindictiveness } \\
\hline $\mathrm{A}$ & 0 & $\mathrm{~B}$ \\
\hline A & 0 * & B \\
\hline
\end{tabular}

Source: own study.

A reference to reciprocity and vindictiveness is also a commonly known phrase 'An eye for an eye, and a tooth for a tooth'. This phrase has been used both in the Code of Hammurabi, as well as in the Bible (Exodus 21:24, Exodus, 21:24), and in the Quran (5:45). However, in the New Testament (Gospel of St. Matthew 5: 38-40), these words to a greater extent refer altruism: 'You have heard that it was said 'Eye for eye, and tooth for tooth'. But I tell you, do not resist an evil person. If anyone slaps you on the right cheek, turn to them the other cheek also. And if anyone wants to sue you and take your shirt, hand over your coat as well'. The Church speaks in a similar vein also in less formal statements. For instance, on August 23, 2014 Pope Francis wrote on his Tweeter: 'Christians knows how to give. Their lives are filled with generous acts - often hidden - towards their neighbour.'

It would seem that altruistic behaviours can lead to long-term problems resulting from the elimination of such units in confrontation with selfish entities (Darwin's theory). However, fortunately altruistic persons undertake their behaviours thinking also about the emotional closeness or the assessment of probability of future interaction and this results from the human pro-social behaviour (Osiński, 2009).

Table 1 shows the personal traits affecting the exchange process, however, it is also necessary to refer to a number of external factors which also affect it.

The scope of benefits received and transmitted within the exchange process depends, first of all, on the possibility to withdraw from the exchange. We adopt a different approach to the exchange when it is mandatory, and act quite differently when it is voluntary. Obviously, exchange depends also on the number of participants involved in the exchange process. If on one side there is a large group of 'beneficiaries' which must be supported by an innumerous group, then their liabilities are far more substantial than the benefits delivered by the entire community to the individual.

Each benefit may be interchangeable in a variety of relationships: direct negotiated (money), direct reciprocal (advice, information), and indirect generalized (status) (Molm, Collett \& Schaefer, 2007). Indirect generalized exchange produces greater solidarity than other benefits, because people assess, in accordance with the social equity theory, the relationship resulting benefits in relation to expenditures in comparison with other people. This indicates that preserving a more favourable effort-effects relation than that of other exchange participants is more important than the received object of exchange or the benefits/cost relationship for the own exchange process ${ }^{4}$ (Park et. al., 2010). Obviously, the process of exchange is impacted by external factors such as, for instance, the political system, the economic system, or a state of war. We perceive our decisions in a different way when we live in a time of peace, and we think differently about our decisions during the war, when often the only effect that we want to achieve is the desire to survive. Of course, mutual interest is of a great importance, too. We can give more, if something is a mutually beneficial exchange, e.g., sponsorship.

At the end, it must be emphasised the final product of the exchange process must be specified (or evaluating the

${ }^{4}$ A similar issue is presented in the Gospel of St. Matthew (20: 1-16a), in which workers were satisfied with their earnings until other workers received the identical amount for the same but definitely shorter work. 
issue on the part of the recipient - the product starting another exchange process), that is the benefit. In the process of exchange each of the parties as part of reciprocation can offer not only money - being the most commonly perceived (and not only today) element of exchange but also love, status, information, goods, and services (Foa \& Foa 1980). Clark \& Wilson (1961) determine the above individual incentives in a different way and they mention 1) material incentives, 2) solidary incentives and purposive incentives. The author proposes to refer to benefits as to material benefits (everything that can be measured directly, including money), social benefits (benefits of belonging to a group such as status) and personal benefits (benefits concerning a person: love, satisfaction, self-realization, sex).

It must be emphasized that we also (or mainly) undertake social contact to gain a certain dose of 'stroking' - e.g., benefits as a result of the exchange process (Berne, 1967). And finally, a sex is very important - men and women have different needs in a relationship. If they receive what they want, they will more likely to return more (Leclerc-Madlala, 2003).

Figure 1 illustrates the entire exchange process. Every interaction between two persons or between a person and the society is submitted to the dependencies presented.

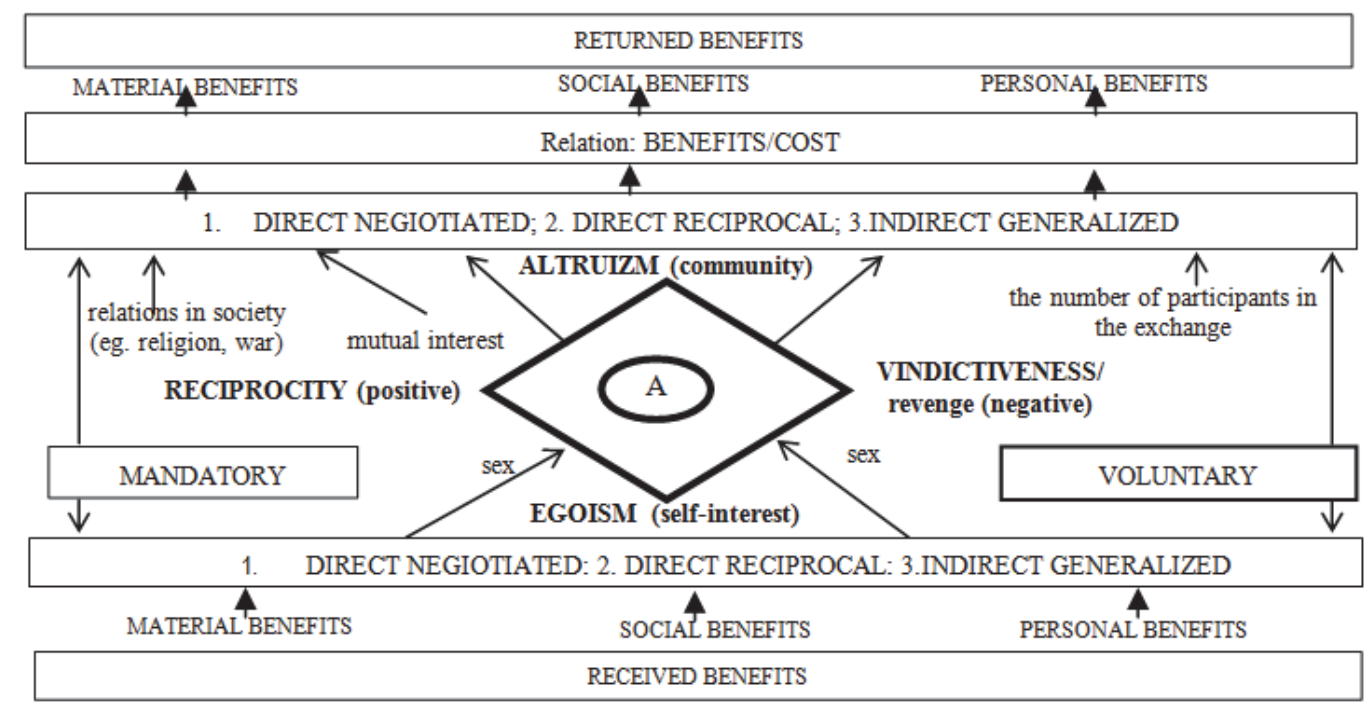

Figure 1: Factors of exchange process in communities (or between persons)

Source: own study based on: (Meeker, 1971), (Foa \& Foa, 1980), (Clark \& Wilson, 1961).

The above regularity in making decisions regarding the exchange process can operate efficiently if the principle on the complete information on all external factors affecting the decision is maintained (more on the role of information in decision-making - according to agency relationship - in Barron \& Gjerde, 1997; Eisenhardt, 1989). In this scope the broadly understood principal (society) is obliged to set up an efficient system for circulating information so that the system could work properly and no one could use the asymmetry of information in order to gain personal benefits. The asymmetry of information may function in the long-run and foster irregularities within the exchange process, for instance, due to the lack of assessment of benefits/cost relation within the scope of own actions or by comparing the relation with other participants of the exchange.

It is also important, which was not resolved by the author, to determine the ratio of the impact of individual characteristics of a person and external conditions on the exchange process. Are human qualities more important, because man as a rational being makes his own decisions, or to a greater extent he is dependent on social factors as the subject of continuous interactions with society?

\section{Solidarity and Creating the Community of Responsibility}

Solidarity or social solidarity is understood by Macneil (1986) as a state of minds which aims to contribute to the harmonious affirmative cooperation and in the presented Figure 1 may mean the point marked with the letter $\mathrm{A}$. It reflects a situation in which an individual, on the one hand, wants to reciprocate for the benefits received, however, on the other 
hand, he/she will not be inclined to 'overdo' the transferred benefits. This individual thinks about others, but also takes care of himself/herself. Due to a rational solution that can be referred to as 'middle', the individual builds long-term cooperation based on mutual cooperation and not making use of others ${ }^{5}$. The example of the affirmative cooperation presented by Macneil is based on similar assumptions - husband going out to sea to fish to provide food for the family knows that he is obliged to feed his family (altruism and reciprocity), at the same time realizes that in the absence of fishing he 'finds less plantain in his bowl or pleasure in his bed in the future'. The awareness of this possibility and care for oneself (egoism) mobilize him to work. All parties also realize that as a result of vindictiveness the situation that emerged may in the future be only intensified which further motivates them to cooperation ${ }^{6}$.

It should also be pointed out that solidarity can be discussed only if all relations in the exchange process are preserved ${ }^{7}$. Any disruption of this process can cause long-term effects. The nature of solidarity gives a strong incentive for every member to monitor each other (Yamagishi \& Mifune, 2009). So any lack of reciprocity, or recognising by any of the parties that in some case someone's benefits/cost relationship has been disturbed, will initiate attempts to take revenge (or lack of reciprocity) and disorder of the whole system that is long-term and difficult to reverse. At the same time an important manifestation of solidarity is that people; generally cooperate more with members of their own group than with outsiders (Yamagishi \& Mifune 2009). For this reason, any disturbance of the afore-mentioned regularity may result in a greater feeling of the said irregularities in the exchange process, which may be irreversible in the short term.

According to the author, a correct, long-term and feasible exchange process based on solidarity is mutual loyalty and agreement between all subjects (or people) within the group aimed to maximize the common interest $\left(u_{t}\right)^{8}$. Such an exchange is based not only on the assessment of the own exchange process in the aspect of the benefits/cost relation, but also on making similar comparisons with other participants of the exchange process, which, as a whole, can be understood as the individual ratio of utility of exchange (benefits/cost) $\left(u_{i}\right)$.

On the one hand, the whole community can function efficiently in terms of exchange and in accordance with the principle of solidarity, providing each unit recognizes its exchange for beneficial in the aspect of the benefits/cost and of course this relationship is beneficial also in relation to other units (1). For example, if there is a single professional group which feels disadvantaged in the field of pensions, then the entire replacement process is inappropriate. On the other hand, however, even if all individuals believe their exchange to be favourable, a holistic view of the process for the whole society can be positive or not (2). All units may feel that the state ensures them with a good life, and all are treated similarly in the exchange, but if the state makes this, for example, at the cost of a huge budget deficit, this process is not positive for society as a whole. The state intends to achieve a short-term goal (social satisfaction and political support) and does not work responsibly. This behaviour is in contradiction with the community of responsibility that should built by society.

$u_{i}$ - individual ratio of utility of exchange (benefits/cost)

$u_{t}-$ utility of exchange (mutual interest) for society

$u_{t}>0$ if each $u_{i}>0$

but

If each $u_{i}>0 \quad$ then it is possible than $u_{t}>0$

The above mentioned community of responsibility ${ }^{9}$ in terms of exchange should not be focused only on the process of exchange of individuals, or even of the entire community, but to a greater extent should be based on the principle of sustainable development, namely on resource management, so as not to limit the developmental opportunities of future generations.

\footnotetext{
${ }^{5}$ The circle representing solidarity must be perfect in the middle, any deviation in either direction causes that the exchange process takes place for the benefit of one of the parties (a unit, the community; more in Meeker, 1971).

${ }^{6}$ It should also be emphasized that feeding the family is the obligation of the parents ('Mandatory'), which the father is obliged to implement individually or jointly with his wife ('the number of participants in the exchange').

${ }^{7}$ An equally important question in terms of solidarity can be a matter of increased taxation of the wealthy, in order to reduce disparities of income in the society. Admitting disparities may (or leads) to an increase in crime, social worries, etc. - which is also, of course, not in the interest of the wealthy (Hsieh \& Puch, 1993). Therefore, if we want to reach a genuine balance between the interests of the poor and the rich, individuals and societies (i.e., reducing crime), it is in the interest of all to share part of income by wealthier members of society (Adamiak, Chojnacka \& Walczak, 2013).

${ }^{8}$ At the same time some important elements of modern society should be emphasised. Can the present in most world economies mechanism of political rent seeking be considered as a social exchange, or is it the official form of corruption (Morck \& Young, 2004)?, or is it individual acquiring to a greater extent of certain benefits or offering one's time (e.g. by voting in elections) in exchange for caring for one's own interests?

${ }^{9}$ Kilanowski (2013) uses the term „freedom as responsibility” as a condition for the individuals and communities development.
} 
Table 2 shows the conditions of the creation of the community of responsibility in society, which may represent a further stage in the development of society. Primitive peoples focused on the process of exchange which was favourable from their own point of view. Of course, in the meantime solidaristic approach to the process of exchange was developed. Solidarity was based (and still is based) on the individual's responsibility for the community and the community' responsibility for the individual - on activities of common interest, which creates a community of solidarity. However, at present the exchange process should be approached far more broadly and creating the community of responsibility should be considered. This community should be based on the satisfaction of individuals with their own process of exchange and public concern about the individual (and vice versa). Additionally, both individuals and community should be obliged to take care to ensure a dignified life for future generations and live together like a sustainable community - in accordance with the principle of sustainable development (Gabrusewicz, 2013; Roseland, 2000). The concern about the future should not be limited solely to the economic (efficiency and competitiveness, balanced budgets, etc.) and environmental (clean and undevastated environment, etc.) aspects but also it should cover social one (security and political stability, etc.). These activities do not need to be directly organized by individual units - for instance, every person may be held responsible for ecological activities individually or through collaboration with institutions that are characterized by such activities (e.g., financial institutions) (Dziawgo, 2003).

Table 2. Factors conditioning the creation of the community of responsibility

\begin{tabular}{|c|c|c|c|}
\hline \multicolumn{3}{|c|}{ Activity } & Dimensions \\
\hline \multirow{2}{*}{1} & \multirow{2}{*}{\multicolumn{2}{|c|}{ Exchange process }} & Comparing own exchange (own benefits/cost relation) \\
\hline & & & Comparing with others (comparing with others benefits/cost relation) \\
\hline \multicolumn{4}{|r|}{+} \\
\hline \multirow[b]{2}{*}{2} & \multirow{2}{*}{$\begin{array}{c}\text { Solidarity } \\
\text { (Community of solidarity) }\end{array}$} & individual & An individual's responsibility for the community \\
\hline & & community & $\begin{array}{l}\text { The community's responsibility for an individual (participating in the exchange } \\
\text { process) }\end{array}$ \\
\hline \multicolumn{4}{|r|}{+} \\
\hline 3 & \multicolumn{2}{|c|}{$\begin{array}{c}\text { Sustainable development (Sustainable } \\
\text { community) }\end{array}$} & economic, environmental, social \\
\hline \multicolumn{4}{|r|}{$=$} \\
\hline 4 & \multicolumn{2}{|c|}{ Community of responsibility } & $\begin{array}{l}\text { Keeping the principles following from the exchange process, solidarity and } \\
\text { sustainable development }\end{array}$ \\
\hline
\end{tabular}

Source: own study.

\section{Conclusion}

The exchange process is dependent on a number of aspects that influence taking a specific decision in the scope of exchange. The most frequently described final object of exchange, i.e., material, social or personal benefits constitute only the last part of the exchange. Much more significant are the determinants of the exchange: personal factors which in the author's opinion include altruism, egoism, reciprocity, vindictiveness, or numerous social factors presented in the work.

The presented text indicates the elements necessary to determine the exchange process as a system that can be considered as based on solidarity. To talk about solidarity it is not enough to offer something to someone, but to recognise the exchange as favourable for both parties. Each unit in the exchange process is guided by the dependencies presented in the work. The role of the community is not only taking care to ensure that the process is received positively by individuals but this process ought to be beneficial for the community as a whole, in the short and long-run:

1. in the short-run in the scope of the exchange process for individuals and communities and

2. in the long-run in the scope of the care of the developmental opportunities of future generations.

The proper functioning of the process of exchange, solidarity as seen by the individual and community, and concern for ensuring the prospects of development of future generations are indispensable for the community if it is to be called the community of responsibility.

\section{References}

Adamiak, S., Chojnacka, E. \& Walczak, D., 2013. Social security in Poland - cultural, historical and economical issues. Copernican Journal of 
Finance \& Accounting. 2(2): 11-25. DOI: 10.12775/CJFA.2013.013.

Adamiak, S. \& Walczak D., 2014. Catholic social teaching, sustainable development and social solidarism in the context of social security. Copernican Journal of Finance \& Accounting. 3(1): 9-18. http://dx.doi.org/10.12775/CJFA.2014.001.

Barron, J. M., \& Gjerde, K. P., 1997. Peer pressure in an agency relationship, Journal of Labor economics, 15(2): 234-254. http://dx.doi.org/10.1086/209832.

Berne, E., 1967. Games people play: the psychology of human relationships. New York: Grove Press, 13-15.

Blau, P. M., 1964. Exchange and Power in Social Life. New York: Wiley.

Chybalski, F., 2012. Measuring the multidimensional adequacy of pension systems in European countries (Discussion paper, No. 1204). London, Pensions Institute - Cass Business School, 3.

Clark, P. B., \& Wilson, J. Q., 1961. Incentive systems: A theory of organizations, Administrative Science Quarterly, 6(2): 129-166. http://dx.doi.org/10.2307/2390752.

Cropanzano, R., \& Mitchell, M. S., 2005. Social exchange theory: An interdisciplinary review. Journal of Management. 31(6): 875. http://dx.doi.org/10.1177/0149206305279602.

Dewey, J., 1984. The Later Works, 1925-1953, Vol. 2: 1925-1927, Carbondale: Southern Illinois University Press, 326-329.

Dziawgo, L., 2003. Eco-offers of Banks and Investment Funds: Poland \& International Trends. Toruń: Wydawnictwo Uniwersytetu Mikołaja Kopernika.

Eisenhardt, K. M., 1989. Agency theory: An assessment and review. Academy of management review. 14(1):57-74. http://dx.doi.org/ $10.2307 / 258191$.

Emerson, R. M., 1976. Social exchange theory. Annual review of sociology. 2: 335-359.

Foa, U. G. \& Foa, E. B., 1980. Resource theory: Interpersonal behavior as exchange. In K. J. Gergen \& M. S. Greenberg \& R. H. Willis (Eds.), Social exchange: Advances in theory and research. New York: Plenum.

Gabrusewicz T. 2013. Sustainability accounting - definition and trends. Research Papers of Wroctaw University of Economics, 302: 38-40.

Hsieh, CC. \& Pugh, MD., 1993. Poverty, income inequality, and violent crime: a meta-analysis of recent aggregate data studies. Criminal Justice Review. 18(2), 182-202. http://dx.doi.org/10.1177/073401689301800203.

Kawiński, M., Stańko D., \& Rutecka, J., 2012. Protection mechanisms in the old-age pension systems of the CEE countries. Journal of Pension Economics and Finance, 11(4): 581-605. doi:10.1017/S147474721200008X.

Kilanowski, M., 2013. Ku wolności jako odpowiedzialności, Toruń: Wyd. UMK, 261-265.

Lawler, E. J., 2001. An Affect Theory of Social Exchange. American Journal of Sociology, 107(2): 322. http://dx.doi.org/10.1086/324071.

Leclerc-Madlala, S., 2003. Transactional sex and the pursuit of modernity. Social Dynamics, 29(2): 213-225. DOI: 10.1080/02533950 308628681.

Levi-Straus, C., 1963. Structural Anthropology, Washington: Basic Books, 200-210.

Lin, G., 2009. Higher Education Research Methodology-Literature Method. International Education Studies 2(4): 179-181.

Macneil I. R. 1986. Individual Utility and Social Solidarity, Ethics, 96(3): 567-593

Malinowski B. 1932. Argonauts of the Western Pacific, London: George Routledge \& Sons LTS, , 81-90. https://archive.org/ stream/argonautsofthewe032976mbp\#page/n7/mode/2up

Mauss M. 1966. The Gift. Form and fuctions of exchange in Archaic Societes, London: Cohen \& West LTD, 1-3, 72-73.

Meeker, B. F., 1971. Decisions and exchange. American Sociological Review, 36:485-495. http://dx.doi.org/10.2307/2093088.

Molm, L. D., Collett, J. L. \& Schaefer, D. R., 2007. Building solidarity through generalized exchange: A theory of Reciprocity. American Journal of Sociology 113(1):205-242. http://dx.doi.org/10.1086/517900.

Morck, R., \& Yeung, B., 2004. Family control and the rent-seeking society. Entrepreneurship Theory and Practice 28(4), 391-409. http://dx.doi.org/10.1111/j.1540-6520.2004.00053.x.

Nicolaiddis, K., \& Viehoff, J., 2012. The choice for sustainable solidarity in Post-Crisis Europe [in:] Bajnai, G. et al. 2012. Solidarity: For Sale? The Social Dimension of the New European Economic Governance, Europe in Dialogue, 2012(01): 23-30.

Osiński, J., 2009. Kin altruism, reciprocal altruism and social discounting. Personality and Individual Differences. 47(4): 374-378.

Quran.

Park et. al., 2010. An investigation of perceptions of social equity and price acceptability judgments for campers in the U.S. national forest. Tourism Management, 31(2), 10.1016/.jtourman.2009.02.012.

Paskov, M., \& Dewilde, C., 2012. Income inequality and solidarity in Europe. Research in Social Stratification and Mobility 30(4):415-432.

Roseland, M., 2000. Sustainable community development: integrating environmental, economic, and social objectives. Progress in planning. 54(2): 76-105.

Ross, M. \& Borgmann-Prebil, Y., (eds), 2010. Promoting Solidarity in the European Union, Oxford: Oxford Scholarship Online, DOI:10.1093/acprof:0so/9780199583188.001.0001.

Shtaffeld, R., \& Barak, A., 2009. Factors related to initiating interpersonal contacts on Internet dating sites: A view from the social exchange theory. Interpersona: An International Journal on Personal Relationships 3(2): 19-37. http://dx.doi.org/10.5964/ ijpr.v3isupp2.74.

Speth, J. G., 1992. The transition to a sustainable society. Proceedings of the National Academy of Sciences, 89(3): 870-872.

The Bible.

Yamagishi, T., \& Mifune N., 2009. Social exchange and solidarity: in-group love or out-group hate?, Evolution and Human Behavior. 30(4): 229, 235. http://dx.doi.org/10.1016/j.evolhumbehav.2009.02.004. 